\title{
The Possibility of Using Ferromagnetic Sludge Collected During Purification of Water from Spilled Oil Products
}

\author{
Viktors Mironovs \\ Faculty of Civil Engineering of the Riga \\ Technical University \\ Riga, Latvia \\ viktors.mironovs@gmail.com \\ Edmunds Teirumnieks \\ Faculty of Engineering \\ Rezekne Academy of Technologies \\ Rezekne, Latvia \\ edmunds.teirumnieks@rta.lv
}

\author{
Aleksejs Tatarinovs \\ Faculty of Civil Engineering of the Riga \\ Technical University \\ Riga, Latvia \\ alta2003@apollo.lv
}

\author{
Juris Treijs \\ Faculty of Civil Engineering of the \\ Riga Technical University \\ Riga, Latvia \\ juristreijs@inbox.lv
}

\begin{abstract}
Among the various methods of water purification from oil pollution, an active magnetic method using powder sorbents with ferromagnetic properties is taking its place. The main components of the sludge are ferromagnetic sorbent, oil and water. The paper discusses some methods of using sludge extracted from water during its cleaning from oil pollution, regeneration and reuse of the sorbent. Particularly, recommendations on the use of sludge as an active fuel additive are given. The possibility of using sludge as a filler for oxygen-flux cutting of concrete and in the production of road-building materials is another demonstrated possibility.
\end{abstract}

Keywords-powder sorbents, sludge extraction, oxygenflux cutting.

\section{INTRODUCTION}

Oil sludge (OS) is formed during the production processes associated with drilling, processing and transportation of oil products. This type of technological waste is very common and represents a great danger to the environment [1,2]. OS is a primarily subject to recycling, although most of them are still subject to disposal. OS is also formed during the spill response of oil products during various accidents and planned cleaning of containers for their storage. OS may vary significantly by its chemical composition and physical properties. This is determined to a large extent by the type of sorbent used in processing technologies. It should be emphasized that the sludge as a whole is quite complex physico-chemical mixtures consisting of petroleum products, metal oxides, mechanical impurities, sand and water [3].

The method of water purification from contamination by oil products using powder sorbents with ferromagnetic properties is effective when working in hard to reach places. When using them, no harmful chemical materials are used [4]. Great possibilities of the method are opening up in connection with the development of new mechanized magnetic devices for the removal of sludge [5]. However, the method is not without flaws, the main of which are relatively low sorption rate and low buoyancy of sorbent. These disadvantages can be eliminated by creating composite sorbents with improved properties [6,7]. The development of recycling technologies and the utilization of ferromagnetic oil sludge (FOS) is also important.

In experimental evaluation of FOS, various methods are used to separate the solid and liquid phases, particularly, by steaming and drying [8.9]. For large volumes, a more complex scheme of splitting the FOS exist using centrifugation and special chemicals. By centrifuging the sludge, one can get up to $10-12 \mathrm{~m}^{3}$ per hour of purified petroleum product, which can be utilized subsequently as an additive to the fuel [10].

There are known some quite effective ways of utilizing the FOS, in particular, drilling sludge. For example, modified peat, lime, and mineral fertilizers are introduced into waste drilling sludge [11]. All this content is mixed till obtaining a loose mass, stored in piles and covered with a polymer film. Before fertilization in the ground, physical and chemical indicators of the mixture are additionally averaged, and the plot is dug up and then sown with herbs or planted with trees.

\section{MATERIALS AND METHODS}

We investigated the FOS obtained when extracting motor oil from water using the developed magnetic technology [7]. Ferromagnetic sorbents are based on fine iron powders (CF) and crushed mill scale (CFO) specified in Table 1. 
TABLe 1 Ferromagnetic SORBEnts

\begin{tabular}{|l|c|c|c|c|}
\hline $\begin{array}{c}\text { Sor- } \\
\text { bent }\end{array}$ & $\begin{array}{c}\text { Iron con- } \\
\text { tent, } \%\end{array}$ & $\begin{array}{c}\text { Average } \\
\text { particle size, } \\
\text { microns }\end{array}$ & $\begin{array}{c}\text { Particle } \\
\text { shape }\end{array}$ & $\begin{array}{c}\text { Bulk } \\
\text { density, } \\
\text { g/cm }\end{array}$ \\
\hline $\mathrm{CF}_{0}$ & $97-98$ & $40-50$ & Spherical & 2.05 \\
\hline $\mathrm{CF}_{1}$ & $97-98$ & $15-20$ & Dendritic & 1.75 \\
\hline $\mathrm{CF}_{2}$ & $75-77$ & $30-40$ & Dendritic & 1.80 \\
\hline $\mathrm{CFO}_{1}$ & $70-72$ & $40-50$ & Petal & 2.35 \\
\hline $\mathrm{CFO}_{1}$ & $75-78$ & $20-25$ & Round & 2.12 \\
\hline
\end{tabular}

For the research of the sorption process, motor oil was used, which was poured previously on the water surface in the form of a film with a thickness of 0.5-1.0 $\mathrm{mm}$. A thin layer of powder sorbent was scattered on the surface of the spill. The sorption process manifested by the saturation of the sorbent during 5-10 minutes. With longer exposures, the sorbent, together with oil, was formed clots that sank to the bottom of the vessel. With decreasing particle size of the sorbent, its buoyancy increased and the dive slowed down to several hours.

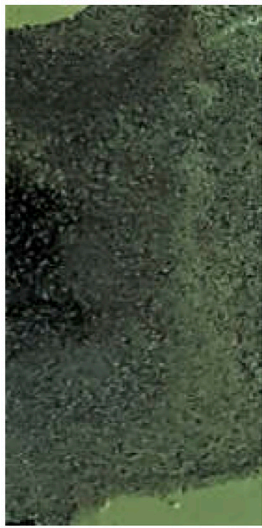

a)

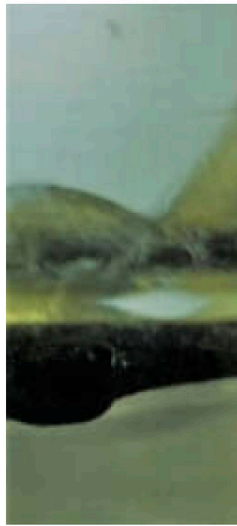

b)

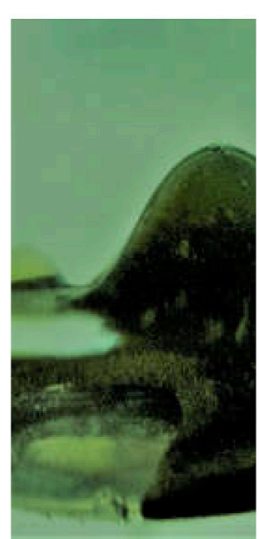

c)
Fig. 1. Use of ferromagnetic sorbent: powder application (a), sorption

$$
\text { process }(b, c) \text {. }
$$

Extraction of sorbents was carried out using magnetic and electromagnetic devices, the effect of which was demonstrated $[4,13,14]$. When using iron powders up to 20 microns in size, the FOS content after rising out of the water was the following: $20-25 \%$ of oil products, $30-35 \%$ of water and $30-40 \%$ of the solid phase (iron oxides). FOS was dried on the air. In the final product, the water content can be reduced to 3-5\%. Periodically, the material should be loosened.

\section{RESUlTS AND DISCUSSION}

\section{A. Evaluation of the possibility of FOS regeneration}

Preliminary tests have shown that the processing of the sorbent in oil, the subsequent drying and calcination can increase its efficiency. This can be explained by wetting effects. To study this issue, experiments were carried out on sorbents made on the basis of iron powder M20 / 80-19 with an average particle size of 30 microns. Engine oil was used as the oil component distributed on the surface of the water. The initial bulk density of the powder sorbent $\mathrm{CF}_{0}$ was $2.05 \mathrm{~g} / \mathrm{cm}^{3}$, and after calcination it was reduced to $1.90-1.95 \mathrm{~g} / \mathrm{cm}^{3}$. The extraction of the FOS mixture from water was performed using a permanent magnet $\mathrm{SmNdB}$. The sorption degree was estimated by the standard method [14]. Studies have shown that sorption efficiency increases by $10-15 \%$ after pressing oil product and heat treatment of the sorbent (Table 2).

TABle 2 The RESUlts OF THE REUSE OF FOS SORBENTS AFTER REGENERATION

\begin{tabular}{|l|c|c|}
\hline Specimen & $\begin{array}{c}\text { Calcination temperature } \\
\text { on air } \\
\text { during } \mathbf{3 0} \mathbf{~ m i n},{ }^{0} \mathrm{C}\end{array}$ & $\begin{array}{c}\text { Residual } \\
\text { content of oil } \\
\text { product, } \%\end{array}$ \\
\hline $\mathrm{CF}_{0}$ & - & $12-14$ \\
\hline $\mathrm{CF}_{1}$ & 200 & $8-10$ \\
\hline $\mathrm{CF}_{2}$ & 300 & $4-6$ \\
\hline $\mathrm{CF}_{3}$ & 400 & $6-8$ \\
\hline
\end{tabular}

The greatest effect was obtained at the calcination temperature $300{ }^{\circ} \mathrm{C}$.

\section{B. Possible applications of FOS in the production} of building materials

One of the most acceptable application for FOS can be additive to the binder in order to improve the quality of the asphalt concrete mix [14]. In our preliminary studies using FOS, pre-building mixture containing sand and crushed stone was heated to a temperature of $200-220{ }^{\circ} \mathrm{C}$, and then viscous bitumen with a temperature of $140-$ $160{ }^{\circ} \mathrm{C}$ was introduced. The mixture was finally stirred. The best results were obtained with the introduction of FOS of the content of $10-15 \%$. This ensured complete enveloping of the material and allowed to save bitumen. In our opinion, FOS can be also used for the production of expanded clay, since the introduction of organic additives helps to reduce the bulk density of clay.

\section{The possibility of using FOS for cutting concrete}

In the course of the research, it was suggested that FOS can be a good powder filler for oxygen-flux cutting of concrete. This technology is already used to create small-diameter holes in columns, walls and ceilings, and cuttings in old building foundations [15]. The method can be used in road construction.

In this work, an oxygen lance (Fig. 2a) was used for the experiments, which is a steel pipe with an outer diameter of $25 \mathrm{~mm}$, a wall thickness of $0.8 \mathrm{~mm}$ and a length of 1.5-2.0 m. The pipe was filled with pre-dried FOS. From a cylinder through the hose connected to the pipe, oxygen was supplied under a pressure of $0.5 \mathrm{kgf} /$ $\mathrm{cm}^{2}$. At the exit, gas was set on fire. When burning, the spear also melted and a hole is formed in the concrete. It is also possible to use the method for burning holes in metal (Fig. 2b).

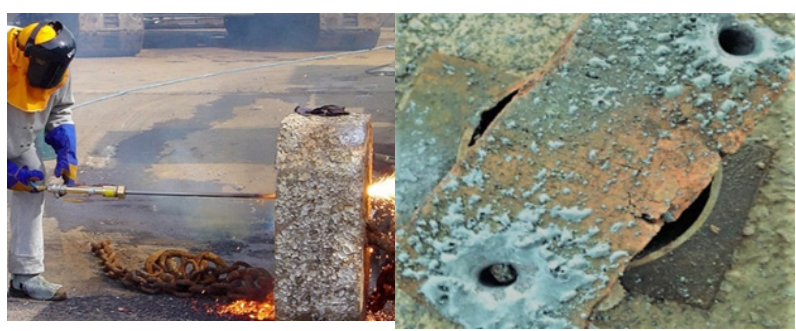

a)

b)

Fig. 2. Burning of holes using an oxygen powder lance in a $300 \mathrm{~mm}$ thick concrete sample (a) and burning holes in a steel strip $20 \mathrm{~mm}$ thick (b). 
Up to $300 \mathrm{dm}^{3}$ of oxygen was required to burn $1 \mathrm{~kg}$ of a lance, created in the form of a tube of low carbon steel. A powder lance differs from a rod lance in that iron powder or their mixture with aluminium powder is supplied to the cutting zone. Burning such material causes additional heat. When cutting with an oxygen-flux spear, the oxygen consumption was up to $50 \mathrm{~m}^{3}$ per hour, and the consumption of dried FOS was 300-500 g/min.

\section{CONCLUSION}

1. The best indicators of sorption in iron powders with a dendritic particle shape.

2. The calcination of the sludge at temperatures of 300 $400{ }^{\circ} \mathrm{C}$ give the opportunity to reuse the ferromagnetic sorbent. When this sorption increases by $6-8 \%$.

3. Sludge with a ferromagnetic sorbent can be used as a filler for gas-thermal cutting of concrete.

\section{REFERENCES}

[1] Mazlov E., Mesherjakov S. Problems of disposal of sludge and methods for their processing / in russian/ Проблемы утилизации нефтешламов и способы их переработки / NooSfera, $2001.56 \mathrm{p}$.

[2] Response to Marine Oil Spills. International Tanker Owners Pollution Federation Ltd. London, 1987.

[3] Sokolov L. Processing and disposal of oily waste /in russian - Переработка и утилизация нефтесодержащих отходов/. Infra-Injenerija, 2017. 137 p.

[4] Mironovs V., Treijs J., Teirumnieks E. Research of Oil Product Sorbtion Process by Ferromagnetic Sorbents. In Proceedings of the $10^{\text {th }}$ Int.Sc.and oractical Conference, Enviroment. Technology, Resources.Vol.1, pp.153-156.Rezekne,Latvija. DOI:http:// dx.doi.org/10.17770/etr 2015.voll.621.
[5] Shishkin A. at all . Ferromagnetic sorbents for collection and utilization of oil products// Key Eng. Mater., 2014, 604, pp.122125.

[6] Ferromagnetic sorbent / Aut. Šiškins A., Mironovs V., Treijs J., / LV Patent 14820 B.

[7] Sorbent with ferromagnetic properties / Aut. Šiškins A., Mironovs V., Treijs J., Baroniņš J. / LV Patent 14822 B.

[8] Patent RU 2361644. The method of separation of solid and liquid phases. / Aut.: Stefansky R., Uilsac R.,Comstoc D., Scott R., Haff D/.

[9] Podvalov Ju. Ecology of oil and gas production / In Russian Экология нефтегазового производства / Moscow, 2010, 416 p.

[10] Markwort L., Wetzel D. KHD Humboldt Wedag ag: Technology and equipment for mineral processing. 2005, https:// mining-media.ru/ru/article/obogach/1322-khd-humboldt-wedag-ag-tekhnologiya-i-oborudovanie-dlya-obogashcheniya-poleznykh-iskopaemykh

[11] Patent RU 2005107571 A, The method of disposal of drilling sludge. / Aut.: petuhova V., Mitrikovsky A., Skilin L., Kozina $\mathrm{Ju}$.

[12] Treijs J, V. Mironovs. Sorbents with Magnetic Properties to Remove Pollution from the Surface of Water and Soil (In Russian -Сорбенты с магнитными свойствами для удалений загрязнений с поверхностей воды и грунта // In 1-rd International Conference on Actual problems of life and ecology. Tver, Russia, 2015, pp.38-43.

[13] Treijs J., Teirumnieks E., Mironovs V. Environmental pollution with oil products and review of possibilities for collection there of. // Vide. Tehnologija. Resursi: 8-th Int.Conf., Rezekne, Latvia, 2011, pp. 301.-309.

[14] Gamazin V., / Technology of use of sludge in the production of asphalt concrete/ in russian: Технология применения НШ при производстве асфальтобетона известна //Экология и промышленность России.- 2003.- № 2, 33 - 37.

[15] Mironov V., Bojko I. The use of metal powders for oxygen-flux cutting materials /in russian: Применение металлических порошков при кислородно-флюсовой резке материалов/ Int. Conf. Welding and related technologies,, 7, Minsk, Belorussia, 2005 , pp. $44-50$ 